\title{
Muscle MRI in TRPV4-related congenital distal SMA
}

Figure Transverse T1-weighted MRI of thighs and calf muscles in distal spinal muscular atrophy (dSMA) patients harboring mutations in transient receptor potential vanilloid 4 (TRPV4)
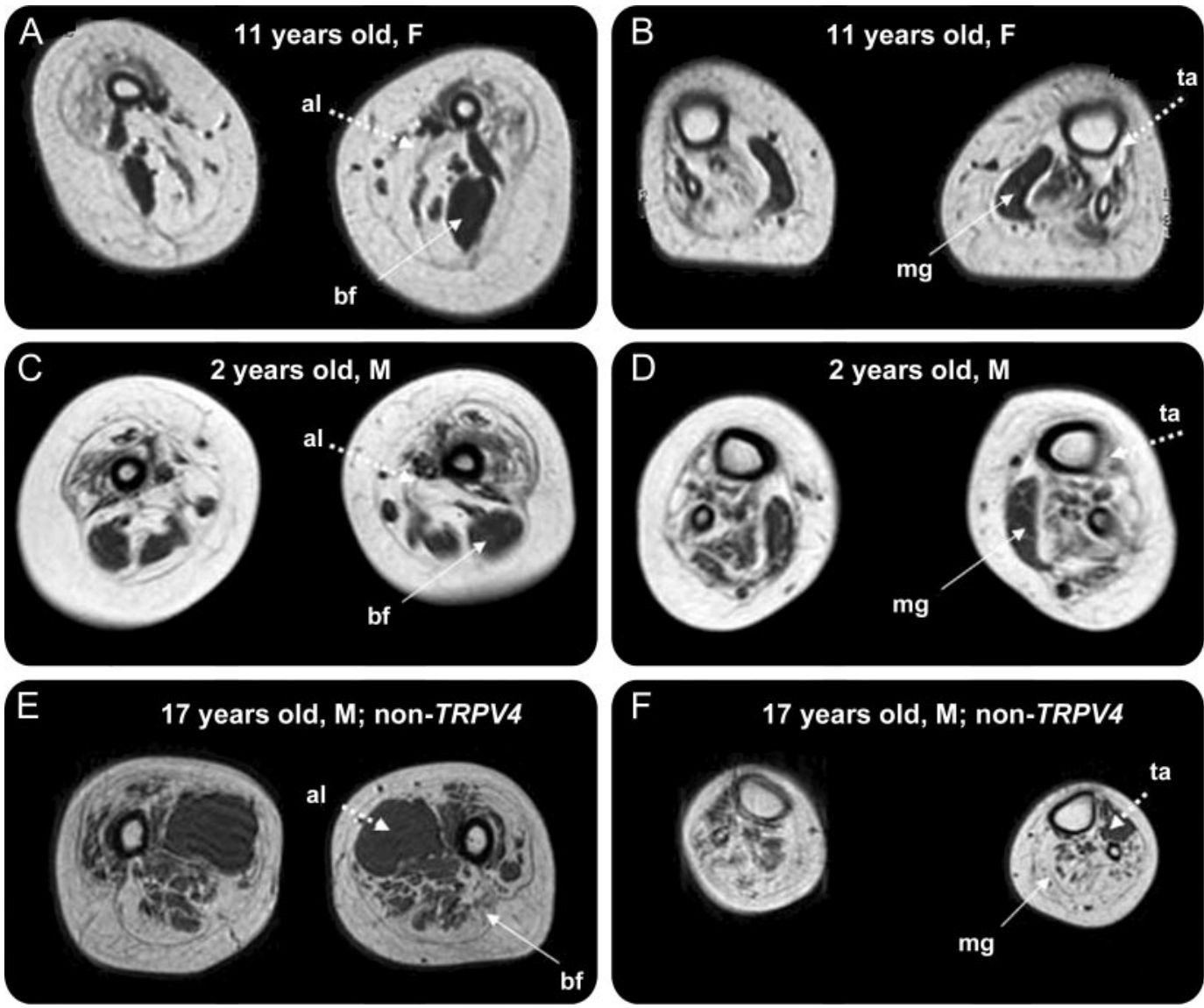

Mutations in the TRPV4 gene ${ }^{1}$ are associated with autosomal dominant congenital dSMA, scapuloperoneal SMA, hereditary motor-sensory neuropathy $2 \mathrm{C}$, and orthopedic clinical conditions ranging from spondylomethaphyseal dysplasia to lethal neonatal metatropic dysplasia. In 2 sporadic patients (A-D) with dSMA harboring de novo mutations in TRPV4, an extensive fatty atrophy preserving biceps femoris (bf) and medial gastrocnemius (mg) was present at muscle MRI. This pattern is different from non-TRPV4 patients ${ }^{2}(\mathrm{E}-\mathrm{F})$ where the medial compartment at thighs (with hypertrophy of adductor longus [al]) and anterior muscles at calf level (tibialis anterior [ta]) are spared.

A 2-year-old boy and an 11-year-old girl showing marked weakness in proximal and distal muscles, atrophy of distal legs, and clubfoot were investigated for congenital spinal muscular atrophy (SMA) as suggested by EMG and muscle biopsy. Both children, who had normal SMN1 gene testing, harbored mutations (p.P97R; p.R232C) in TRPV4. ${ }^{1}$ MRI of muscle showed similar severe changes preserving biceps femoris in the lateral compartment of the thighs and medial gastrocnemius in the posteromedial calves (figure). The pattern of myoimaging, unrelated to disease duration, is not seen in other congenital distal $\mathrm{SMA}^{2}$ and might facilitate appropriate molecular analyses.

G. Astrea, MD, G. Brisca, MD, C. Fiorillo, MD, PhD, M. Valle, MD, M. Tosetti, PhD, C. Bruno, MD, PhD, F.M. Santorelli, MD, R. Battini, MD, PhD, Pisa (G.A., C.F., M.T., F.M.S., R.B.) and Genoa (G.B., M.V., C.B.), Italy 
Author contributions: Study concept and design: Dr. Astrea, Dr. Santorelli, Dr. Bruno. Acquisition of data: Dr. Astrea, Dr. Brisca, Dr. Fiorillo, Dr. Valle, Dr. Tosetti. Analysis and interpretation of data: Dr. Astrea, Dr. Fiorillo, Dr. Bruno, Dr. Santorelli. Drafting of the manuscript: Dr. Astrea, Dr. Fiorillo. Critical revision of the manuscript for important intellectual content: Dr. Astrea, Dr. Brisca, Dr. Fiorillo, Dr. Valle, Dr. Tosetti, Dr. Bruno, Dr. Santorelli, Dr. Battini. Obtained funding: Dr. Bruno. Study supervision: Dr. Astrea, Dr. Santorelli.

Study funding: Supported in part by the Italian Ministry of Health, Regione Toscana grant RR5/09-RT (to C.B.) and Fondazione Telethon (Grant GUP08005 to C.B.).

Disclosure: Drs. Astrea, Brisca, Fiorillo, Valle, and Tosetti report no disclosures. Dr. Bruno receives research support from Regione Toscana and Telethon Foundation Italy Drs. Santorelli and Battini report no disclosures.

Correspondence \& reprint requests to Dr. Santorelli: filippo3364@gmail.com and to Dr. Astrea: gastrea@inpe.unipi.it

1. Auer-Grumbach M, Olschewski A, Papic L, et al. Alterations in the ankyrin domain of TRPV4 cause congenital distal SMA, scapuloperoneal SMA and HMSN2C. Nat Genet 2010;42:160-164.

2. Mercuri E, Messina S, Kinali M, et al. Congenital form of spinal muscular atrophy predominantly affecting the lower limbs: a clinical and muscle MRI study. Neuromuscul Disord 2004;14:125-129.

\section{NeuroImages Are Free at www.neurology.org!}

All Neurology ${ }^{\circledR}$ NeuroImages can now be freely accessed on the Neurology Web site. See them at www.neurology.org, where you can also sign up for journal email alerts and check out other online features, including the Resident \& Fellow section, Neurology: Clinical Practice, and the weekly Neurology Podcasts. 


\title{
Neurology
}

\author{
Muscle MRI in TRPV4-related congenital distal SMA \\ G. Astrea, G. Brisca, C. Fiorillo, et al. \\ Neurology 2012;78;364-365 \\ DOI 10.1212/WNL.0b013e318245295a
}

This information is current as of January 30, 2012

\section{Updated Information \& Services}

References

Citations

Subspecialty Collections

Permissions \& Licensing

Reprints including high resolution figures, can be found at: http://n.neurology.org/content/78/5/364.full

This article cites 2 articles, 0 of which you can access for free at: http://n.neurology.org/content/78/5/364.full\#ref-list-1

This article has been cited by 2 HighWire-hosted articles: http://n.neurology.org/content/78/5/364.full\#\#otherarticles

This article, along with others on similar topics, appears in the following collection(s):

\section{All Genetics}

http://n.neurology.org/cgi/collection/all_genetics

All Neuromuscular Disease

http://n.neurology.org/cgi/collection/all_neuromuscular_disease

All Pediatric

http://n.neurology.org/cgi/collection/all_pediatric

MRI

http://n.neurology.org/cgi/collection/mri

Information about reproducing this article in parts (figures,tables) or in its entirety can be found online at:

http://www.neurology.org/about/about_the_journal\#permissions

Information about ordering reprints can be found online:

http://n.neurology.org/subscribers/advertise

Neurology ${ }^{\circledR}$ is the official journal of the American Academy of Neurology. Published continuously since 1951, it is now a weekly with 48 issues per year. Copyright Copyright (? 2012 by AAN Enterprises, Inc.. All rights reserved. Print ISSN: 0028-3878. Online ISSN: 1526-632X.

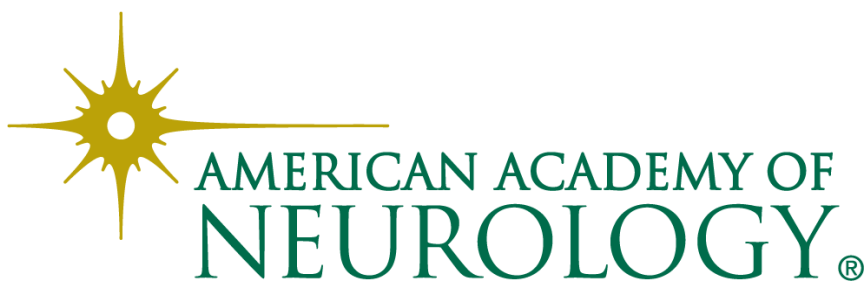

